\title{
PENGGUNAAN MEDIA KARTU SUKU KATA UNTUK MENINGKATKAN KEMAMPUAN MEMBACA PERMULAAN SISWA SEKOLAH DASAR
}

\author{
Umar Yampap ${ }^{1}$, Suryadin Hasyda ${ }^{2}$ \\ ${ }^{12}$ Pendidikan Guru Sekolah Dasar, ${ }^{1}$ Universitas Musamus, ${ }^{2}$ Universitas Muhammadiyah Kupang \\ yampap_fkip@unmus.ac.id
}

\section{INFO ARTIKEL}

Riwayat Artikel:

Diterima:09-Agustus-2021

Disetujui:28-September-2021

\section{Kata Kunci:}

Media Kartu Suku Kata,

Kemampuan Membaca

Permulaan

\section{ABSTRAK}

\begin{abstract}
Abstrak: Penelitian ini bertujuan untuk meningkatkan kemampuan membaca permulaan dengan menggunakan media kartu suku kata kelas 2 SD Inpres Kampung Baru Merauke. Jenis penelitian ini adalah penelitian tindakan kelas yang bersiklus melalui empat tahap yaitu, perencanaan, pelaksanaan, observasi, dan refleksi. Hasil penelitian dapat diketahui bahwa dengan menggunakan media kartu suku kata siklus I pertemuan I sebesar 2.45, pertemuan II 2.54. Sedangkan aktivitas siswa pertemuan pertama 2.52 dan pertemuan kedua 2.54 dengan kategori cukup aktif. Hasil nilai rata-rata kemampuan membaca permulaan siklus I sebesar 64.063 dengan kategori cukup. Keaktifan guru siklus II pertemuan I sebesar 3.65, pertemuan II 3.75 kategori sangat baik. Aktivitas siswa pertemuan I 3.55, pertemuan kedua 3.65 kategori baik. Sedangkan hasil kemampuan membaca permulaan dapat dilihat dari nilai rata-rata siklus II 75.39 kategori baik. Dengan demikian, penggunaan media kartu suku kata dapat meningkatkan kemampuan membaca permulaan siswa kelas 2 SD Inpres Kampung Baru Merauke.
\end{abstract}

Abstract: This study aims to improve early reading skills by using syllable card media for grade 2 SD Inpres Kampung Baru Merauke. This type of research is classroom action research which cycles through four stages, namely, planning, implementation, observation, and reflection. The results of the study can be seen that by using syllable card media, the first cycle of the first meeting is 2.45 , the second meeting is 2.54. While the activity of the students in the first meeting was 2.52 and the second meeting was 2.54 with a fairly active category. The results of the average reading ability at the beginning of the first cycle of 64,063 with a sufficient category. The activity of the teacher in the second cycle of the first meeting was 3.65, the second meeting was 3.75 in the very good category. Student activity in the first meeting is 3.55, the second meeting is 3.65 in good category. While the results of the initial reading ability can be seen from the average value of the second cycle of 75.39 in the good category. Thus, the use of syllable card media can improve the early reading ability of 2 nd graders of SD Inpres Kampung Baru Merauke.

\section{d.) Crossnet}

\section{A. LATAR BELAKANG}

Kegiatan membaca adalah menangkap apa yang tersirat dari bahan yang tersurat. Kesanggupan seseorang dalam membaca atau menangkap amanat yang tersirat dari bahan yang tersurat serta mengarahkan pada lambang-lambang tertulis dengan lafal dan nada yang tepat tidak sama atau berbeda-beda satu sama lainnya (Aulia, 2012). Hasil observasi siswa kelas 2 SD Inpres Kampung Baru Merauke masih kesulitan membaca, misalnya dalam membedakan huruf ' $B$ ' dengan huruf ' $D$ ' atau huruf ' $F$ ' dengan huruf ' $V$ '. Peneliti menemukan hanya 8 siswa dari 31 siswa yang sudah lancar membaca. Sedangkan 24 siswa lainnya belum lancar membaca dan masih sulit menggabungkan suku kata, sehingga siswa belum lancar membaca.

Berdasarkan masalah di atas, dalam proses pembelajaran berlangsung guru kurang memanfaatkan media yang melibatkan siswa untuk memperoleh pengalaman belajar, sehingga pembelajaran yang dilaksanakan menjadi kurang bermakna bagi siswa. Oleh karena itu peneliti melakukan perbaikan pembelajaran dengan menggunakan media kartu suku kata.

Kata media berasal dari bahasa latin medius dan merupakan bentuk jamak dari kata medium yang secara harfiah berarti "tengah", "perantara" atau"pengantar". Sadiman (Musfiqon, 2012) mengatakan bahwa media adalah perantara atau pengantar pesan. Sedangkan Briggs (Sisiliana \& Riyana, 2007) berpendapat bahwa media merupakan alat untuk memberikan perangsang bagi siswa supaya terjadi proses belajar. Apabila media itu membawa pesan-pesan atau informasi yang bertujuan intruksional atau mengandung maksud-maksud pengajaran maka media itu disebut media pembelajaran (Arsyad, 2009). Menurut Ratnawati (Suyanto, 2012) bahwa, melalui media kartu suku kata yang di implementasikan melalui permainan, dapat merangsang untuk 
lebih cepat mengenal simbol-simbol huruf, membuat minat anak semakin kuat untuk bereksplorasi dalam menemukan kosakata baru, dengan cara merangkaikan simbol- simbol huruf tersebut. Berbicara mengenai membaca sebagai aktivitas yang kompleks, (Depdiknas, 2007) membaca adalah melihat serta memahami isi dari apa yang tertulis. Putra (2008) menyatakan bahwa membaca permulaan (beginning reading), lebih mendapat penekanan pada pengkondisian siswa masuk dan mengenal bahan bacaan.

Miller (Dhieni, Nurbiana, \& dkk, 2005) mengemukakan bahwa sebelum siswa diajarkan membaca perlu diketahui terlebih dahulu kesiapan membaca anak. Menurut Somadayo (2011) membaca merupakan kegiatan interaktif untuk memetik dan memahami makna yang terkandung dalam bahan tertulis lebih lanjut, dikatakan bahwa membaca merupakan proses yang dilakukan dan digunakan oleh pembaca untuk memperoleh pesan yaang disampaikan oleh penulis. Hal ini bertujuan agar dapat mengetahui apakah siswa sudah siap diajarkan membaca. Membaca Permulaan merupakan tahapan proses belajar membaca bagi siswa sekolah dasar kelas awal. Siswa belajar untuk memperoleh kemampuan dan menguasai teknik-teknik membaca dan menangkap isi bacaan dengan baik (Samsiyah, Sari, \& Sulistyaningrum, 2016). Oleh karena itu guru perlu merancang pembelajaran membaca dengan baik sehingga mampu menumbuhkan kebiasan membaca sebagai suatu yang menyenangkan (Teni, 2019). Mackey (Rofi'uddin \& Zuhdi, 2003) bahwa guru menggunakan strategi permainan membaca misalnya cocokkan kartu itu, ucapkan kata itu, temukan kata itu, kontes ucapan, temukan kalimat itu, baca, berbuat dan sebagainya. Siswa perlu mengembangkan pengetahuan tentang abjad agar menggunakan huruf dan keterampilan bunyi huruf untuk membaca.

Adapun kegiatan yang dapat dilakukan dengan membaca permulaan menggunakan media kartu suku kata sebagai berikut (1) mempersiapkan siswa, (2) menyediakan peralatan (media kartu suku kata), (3) memperkenalkan siswa pada berbagai suku kata, (4) mempraktikkan cara penggunaan media, dan (5) membaca kartu suku kata dan merangkaikan /menggabungkan dua atau lebih suku kata hingga menjadi satu kata.

Berdasarkan latar belakang di atas, maka peneliti merumuskan sebagai berikut, 1) bagaimana penggunaan media kartu suku kata pada siswa sekolah dasar?, bagaimana peningkatan kemampuan membaca permulaan siswa sekolah dasar?

Tujuan dari penelitian ini adalah, 1) untuk mengetahui penggunaan media kartu suku kata, 2) untuk mengetahui peningkatan kemampuan membaca permulaan siswa sekolah dasar. Dasarkan beberapa pendapat di atas, dapat disimpulkan membaca permulaan merupakan kegiatan terpadu yang mencakup beberapa kegiatan seperti mengenali huruf dan kata-kata, menghubungkannya dengan bunyi, maknanya serta menarik kesimpulan mengenai maksud bacaan.

\section{B. METODE PENELITIAN}

Jenis penelitian ini adalah penelitian tindakan kelas (PTK), yang biasa disebut Classroom Action Research. Penelitian ini memliki empat komponen yang membentuk satu siklus yaitu perencanaan, tindakan, pengamatan, dan refleksi, Lewin (Trianto, 2011).

Tempat penelitian di SD Inpres Kampung Baru Merauke yang beralamat Jl. Pembangunan Kampung Domba, 27/4, Rimba Jaya, Merauke, Papua. Sedangkan waktu penelitian pada semester ganjil tahun ajaran 2021/2022 selama 1 bulan yaitu Juni 2021. Subjek penelitian adalah siswa kelas 2 yang terdiri dari 15 laki-laki dan 16 perempuan dengan jumlah 31 siswa. Peneliti hanya memilih 16 siswa untuk mewakili proses pembelajaran di kelas karena situasi masa pandemi covid-19 di Kabupaten Merauke masih meningkat. Adapun objek penelitian ini adalah penggunaan media kartu suku kata dan kemampuan membaca permulaan.

Instrumen dalam penelitian ini adalah perangkat pembelajaran yang terdiri dari Silabus, RPP, LKS dan Tes. Kemudian instrument pengumpulan data adalah lembar observasi guru, siswa, dan tes kemampuan membaca permulaan. Teknik analisis data pada penelitian ini adalah kuantitatif berupa angka-angka yang diperoleh dari analisis observasi pelaksanaan pembelajaran dan penialain hasil belajar (Sugiyono, 2009). Dalam menganalisis data menggunakan rumus yang sesuai dengan aspek yang ingin diukur oleh peneliti sehingga diperoleh hasil yang tepat dan sesuai untuk menjawab rumusan masalah.

Indikator keberhasilan ini adalah hasil kemampuan membaca siswa secara individu bila telah memperoleh nilai sesuai KKM yang ditetapkan yaitu 65. Sedangkan 70\% dari jumlah siswa mengalami hasil kemampuan membaca klasikal maka penelitian ini dianggap selesai.

\section{HASIL DAN PEMBAHASAN}

Penelitian ini dilakukan 2 siklus dan setiap siklus masing-masing 2 kali pertemuan. Dalam kegiatan inti, peneliti menjelaskan materi dan memberikan kesempatan kepada siswa untuk melakukan membaca permulaan yang sudah disiapkan media kartu suku kata oleh peneliti. Dalam kegiatan penutup peneliti melakukan tes kemampuan membaca permulaan kepada siswa. Setelah siswa melakukan tes membaca peneliti menanyakan 
perasaan siswa selama mengikuti pembelajaran. Hal ini bertujuan untuk mengetahui masukan atau saran dari siswa sebagai refleksi terhadap pembelajaran siklus berikutnya.

Peneliti dibantu oleh teman sejawat sebagai observer untuk melakukan pengamatan aktivitas siswa selama kegiatan pembelajaran berlangsung menggunakan media kartu suku kata. Berdasarkan data hasil observasi kegiatan guru dan siswa pada siklus I pertemuan 1 dan 2 dapat dilihat diagram berikut:

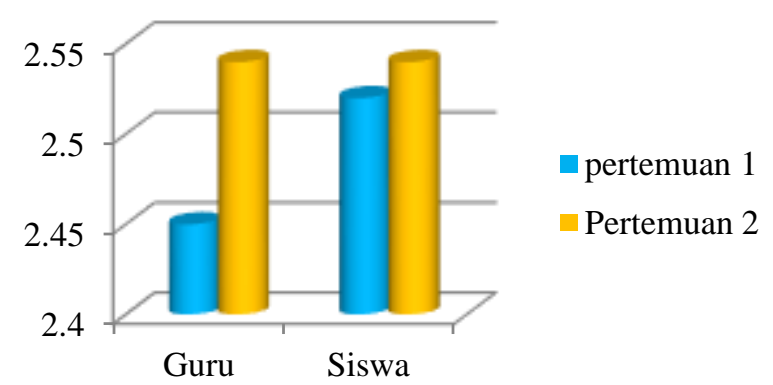

Gambar 1. Hasil aktivitas guru dan siswa

Berdasarkan hasil observasi dalam melaksanakan pembelajaran dengan menggunakan media kartu suku kata pada siklus I terlihat kemampuan guru pada pertemuan pertama 2.45 dan pertemuan kedua 2.54. Sedangkan aktivitas siswa selama kegiatan proses pembelajaran berlangsung pada pertemuan pertama 2.52 dan kedua 2.54 kategori cukup. Dalam penggunaan media kartu suku kata terdapat hasil perolehan nilai siswa terhadap tes kemampuan membaca yang dapat disajikan oleh peneliti. Data tersebut dapat dilihat dilihat diagram berikut:

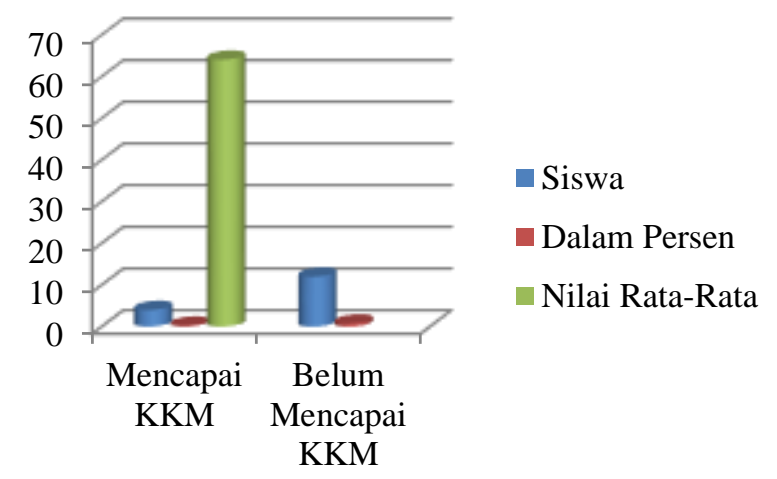

Gambar 2. Hasil kemampuan membaca permulaan pada siklus I

Berdasarkan gambar 2 di atas, ketuntasan hanya 4 siswa yaitu 25\% dan yang tidak tuntas 12 siswa / 75\% dengan nilai rata-rata 64.063 dengan kategori cukup. Tahap selanjunya adalah refleksi, peneliti berdiskusi dengan observer yakni teman sejawat peneliti terhadap pelaksanaan tindakan yang telah dilakukan dan kendala yang ditemukan yaitu memasang kartu suku kata siswa kurang fokus karena masih banyak siswa bermain dengan sesama teman, ukuran huruf kartu suku kata masih terlalu kecil, siswa belum terbiasa dengan media kartu suku kata, dan hasil tes kemampuan membaca permulaan masih banyak siswa yang nilainya belum mencapai. Solusi untuk mengatasi masalah tersebut adalah melakukan tindakan siklus II. Oleh karena itu peneliti merencanakan perbaikan tindakan yang akan dilakukan pada siklus kedua.

Siklus kedua dalam proses kegiatan inti, siswa dibagi kelompok kecil, yakni satu kelompok terdiri atas 5-6 orang. Peneliti kemudian membagi LKS kepada setiap kelompok. Peneliti menjelaskan cara mengerjakan LKS tersebut. Peneliti mengkondisikan siswa agar berdiskusi dengan teman satu kelompoknya. Siswa menyusun kartu suku kata tersebut menjadi sebuah kalimat dan memahami kalimat tersebut. Siswa yang lebih cepat menyusun kartu suku kata menjadi sebuah kalimat yang benar menjadi pemenang. Siswa membacanya sesuai kartu suku kata yang telah disusun secara berpasangan.

Pada akhir kegaiatan, peneliti melakukan tes kemampuan membaca permulaan kepada siswa. Setelah melakukan tes membaca peneliti mengadakan tanya jawab tentang penggunaan media kartu suku kata dan membacakan kesimpulan singkat dari materi yang disampaikan. Peneliti dan siswa mengakhiri proses pembelajaran dengan berdo'a.

Keterlaksanaan siklus II menggunakan media kartu suku kata diamati dan ditulis hasil observasi didalam lembar pengamatan dapat dilihat sebagai berikut: 


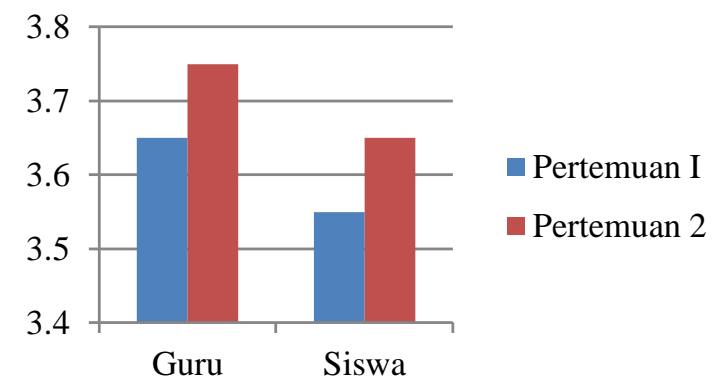

Gambar 3. Hasil observasi guru dan siswa

Pada gambar 3 menunjukan adanya peningkatan aktivitas guru yaitu 3.65 pertemuan pertama dan kedua 3.75 kategori sangat baik. Sedangkan aktivitas siswa pertemuan pertama 3.55 dan kedua 3.65 kategori baik. Pada siklus II terdapat peningkatan kemampuan membaca permulaan pada setiap siswa dapat dilihat pada diagram berikut:

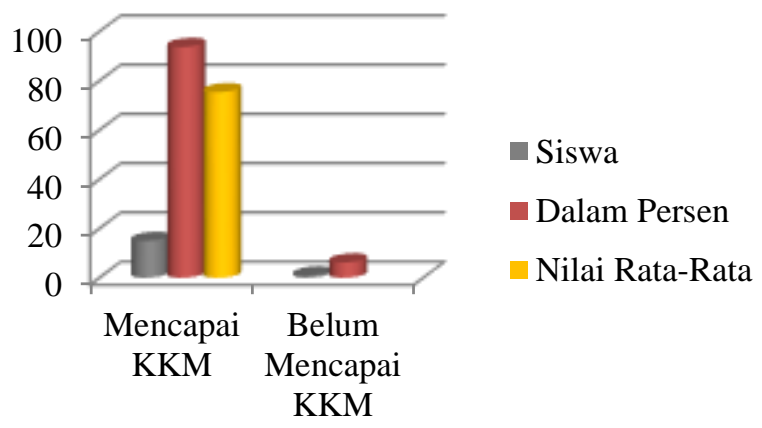

Gambar 4. Hasil kemampuan membaca permulaan

Berdasarkan gambar 4 di atas, bahwa dalam melakukan kemampuan membaca dengan menggunakan media kartu suku kata mengalami peningkatan pada siklus II yaitu 15 siswa atau sebesar $94 \%$ dan yang tidak tuntas 1 orang atau 6\% dengan nilai rata-rata 75.39 kategori baik. Ada 1 siswa tidak mengalami perubahan karena siswa tersebut tidak masuk sekolah pada saat melakukan penilaian pada siklus kedua. Selanjutnya melakukan tahap refleksi siklus kedua, peneliti mengevaluasi tindakan dan menganalisis dampak implementasi tindakan yang telah dilakukan. Kegiatan tersebut dilakukan untuk mengetahui sejauh mana media kartu suku kata dapat mempengaruhi peningkatan kemampuan membaca permulaan siswa pada siklus II. Untuk mengetahui peningkatan hasil kemampuan membaca permulaan pada siklus I dan II dilakukan dengan cara membandingkan mean test seperti berikut:

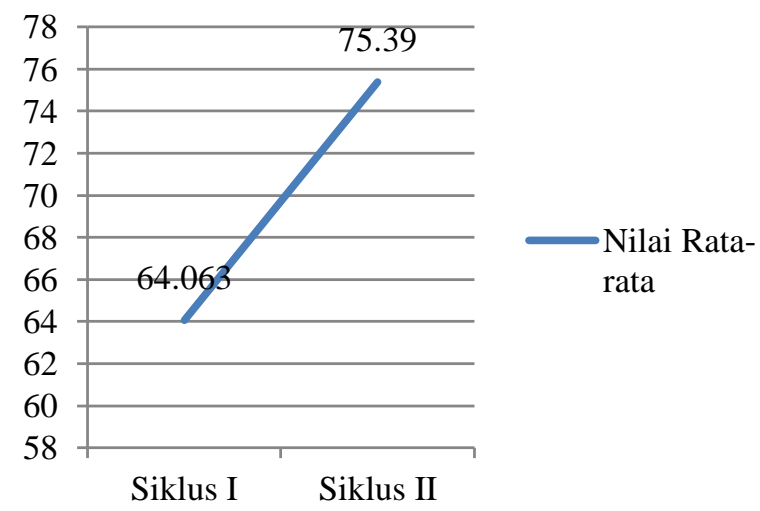

Gambar 5. Nilai rata-raya siklus I dan II

Berdasarkan gambar 5 di atas, pelaksanaan kegiatan penelitian dengan menggunakan media kartu suku kata pada siklus 1 dengan nilai $\Sigma$ rata-rata 64.063 dan siklus II sebesar 75.39 mengalami peningkatan disetiap siklus. Pendapat yang diungapkan oleh Heinich (Sutirman, 2013) bahwa media sebagai perantara yang mengantar informasi dari sumber kepada penerima. Sejalan dengan hasil penelitian yang dilakukan oleh (Mustatiroh, 2016; Istanto, 2014) bahwa media kartu sudah tepat karena media ini dapat membantu siswa dalam kemampuan membaca permulaan meningkat. Jadi, bisa dikatakan bahwa pembelajaran tersebut berhasil. Dengan demikian dari hasil penelitian ini menunjukkan bahwa media kartu suku kata dapat meningkatkan kemampuan membaca siswa kelas 2 SD Inpres Kampung Baru Merauke. 


\section{SIMPULAN DAN SARAN}

Hasil penelitian yang telah dilakukan terdapat adanya peningkatan kemampuan membaca permulaan pada siswa kelas 2 SD Inpres Kampung Baru Merauke, hal ini terbukti efektif dan berdampak positif bagi perkembangan kemampuan akademik pembelajaran menggunakan media kartu suku kata sangat penting dikembangkan untuk meningkatkan kemampuan membaca permulaan siswa.

Berdasarkan hasil penelitian, saran yang dapat diberikan kepada guru yaitu dalam kegiatan belajar membaca permulaan diharapkan menjadikan media kartu suku kata sebagai suatu alternatif yang berkesinambungan dalam kegiatan proses belajar mengajar.

\section{DAFTAR RUJUKAN}

[1] Arsyad, A. 2009. Media Pembelajaran. Jakarta: Raja Grafindo Persada Rineka Cipta.

[2] Aulia, R. 2012. Meningkatkan Kemampuan Membaca Pemahaman Pada Anak Tunarungu. Jurnal Ilmiah Pendidikan Khusus, 1(2), 347-357.

[3] Depdiknas. 2007. Kamus Besar Bahasa Indonesia. (Edisi Ke-3). Jakarta: Balai Pustaka.

[4] Dhieni, Nurbiana, \& dkk. (2005). Metode Pengembangan Bahasa. Jakarta: Universitas Terbuka.

[5] Istanto, B. 2014. Peningkatan Keterampilan Membaca Permulaan dengan Menggunakan Media Kartu Kata pada Siswa Kelas I Sd Negeri 1 Pandeyan Jatinom Klaten. Skripsi Tidak Diterbitkan. Universitas Negeri Yogyakarta.

[6] Musfiqon. 2012. Pengembangan Media Belajar Dan Sumber Belajar. Jakarta: Prestasi Pustaka Karya.

[7] Mustatiroh. 2016. Peningkatan Kemampuan Membaca Permulaan Menggunakan Media Kartu Kata Bergambar Siswa Kelas I SD Negeri Gembongan. Basic Education, 4(10), 940-945.

[8] Putra, M. S. 2008. Menumbuhkan Minat Baca Sejak Dini. Jakarta: P.T Indeks.

[9] Rofi'uddin, A., \& Zuhdi, D. 2003. Pendidikan Bahasa dan Sastra Indonesia di Kelas Tinggi. Jakarta: Depdikbud.

[10] Samsiyah, N., Sari, A. K., \& Sulistyaningrum, Y. 2016. Pembelajaran Membaca Permulaan Melalui Permainan Bahasa Siswa Kelas I Sdn Bulakrejo Madiun. Premiere Educandum. Jurnal Pendidikan Dasar Dan Pembelajaran., 3(02).

[11] Sisiliana, R., \& Riyana, C. 2007. Media Pembelajaran. Bandung: PT. Wacana Prima.

[12] Somadayo, S. 2011. Strategi dan Teknik Pembelajaran Membaca. Yogyakarta: Graha Ilmu.

[13] Sugiyono. 2009. Metode Penelitian Kuantitatif, Kualitatif dan R\&D. Bandung: Alfabeta.

[14] Sutirman. 2013. Media \& Model-model Pembelajaran Inovatif. Yogyakarta: Graha Ilmu.

[15] Suyanto, E. 2012. Perilaku Tokoh dalam Cerpen Indonesia. Bandar Lampung: Universitas Lampung.

[16] Teni, E. 2019. Meningkatkan Kemampuan Membaca Permulaan Menggunakan Media Kartu Kata Bergambar Pada Siswa Kelas I Sekolah Dasar. Jurnal Pembelajaran Prospektif, 4(1), 15-22.

[17] Trianto. 2011. Model Pembelajaran Terpadu Konsep,Strategi dan Implementasinya Dalam Kurikulum Tingkat Satuan Pendidikan (KTSP). Jakarta: Bumi Aksara. 